\title{
The Adaptive Capacity Wheel: A Method to Assess the Inherent Characteristics of Institutions to Enable the Adaptive Capacity of Society
}

\author{
Joyeeta Gupta ${ }^{\mathrm{a}}$, Katrien Termeer ${ }^{\mathrm{b}}$, Judith Klostermann ${ }^{\mathrm{c}}$, Sander Meijerink ${ }^{\mathrm{d}}$, Margo van den \\ Brink $^{\mathrm{d}}$, Pieter Jong ${ }^{\mathrm{e}}$, Sibout Nooteboom ${ }^{\mathrm{f}}$ and Emmy Bergsma ${ }^{\mathrm{a}}$ \\ ${ }^{a}$ Institute for Environmental Studies, VU University Amsterdam, De Boelelaan 1087, 1081 \\ HV Amsterdam, the Netherlands. \\ ${ }^{\mathrm{b}}$ Department of Social Science, Wageningen Agricultural University and Research Centre, \\ Hollandseweg 1, $6706 \mathrm{KN}$ Wageningen, the Netherlands. \\ ${ }^{c}$ Alterra, Wageningen Agricultural University and Research Centre, P.O. Box 47, 6700 AA \\ Wageningen, the Netherlands. \\ ${ }^{\mathrm{d}}$ Nijmegen School of Management, Radboud University Nijmegen, P.O. Box 9108, 6500 HK \\ Nijmegen, The Netherlands. \\ ${ }^{\mathrm{e}}$ Faculty Technology, Policy and Management, Delft University of Technology, Jaffalaan 5 \\ Delft, The Netherlands. \\ ${ }^{f}$ Department of Public Administration, Erasmus University Rotterdam, P.O. Box 1738, 3000 \\ DR Rotterdam, the Netherlands.
}

*Corresponding author. Email address: emmy.bergsma@ivm.vu.nl, telephone: +31 2059 88690

\begin{abstract}
(200)
Climate change potentially brings continuous and unpredictable changes in weather patterns. Consequently, it calls for institutions that promote the adaptive capacity of society and allow society to modify its institutions at a rate commensurate with the rate of environmental change. Institutions, traditionally conservative and reactive, will now have to support social actors to proactively respond through planned processes and deliberate steps, but also through cherishing and encouraging spontaneous and autonomous change, as well as allowing for institutional redesign. This paper addresses the question: How can the inherent characteristics of institutions to stimulate the capacity of society to adapt to climate change from local through to national level be assessed? On the basis of a literature review and several brainstorm sessions, this paper presents six dimensions: Variety, learning capacity, room for autonomous change, leadership, availability of resources and fair governance. These dimensions and their 22 criteria form the Adaptive Capacity Wheel. This wheel can help academics and social actors to assess if institutions stimulate the adaptive capacity of society to respond to climate change; and to focus on whether and how institutions need to be redesigned. This paper also briefly demonstrates the application of this Adaptive Capacity Wheel to different institutions.
\end{abstract}

Key words: climate change, governance, institutions, adaptive capacity, criteria

\section{Introduction}


The global climatic system and human society are continuously changing systems. They sometimes evolve in response to impacts emerging from the other system and sometimes they evolve autonomously (cf. Gilbert 2006). Throughout human history, institutions (social patterns) have reacted incrementally and conservatively to deal with social problems as they are based on cultural practices, deep-rooted lifestyles and ideological premises (Gupta and Dellapenna 2009, Pollitt \& Bouckaert 2000). As such, institutions provide stability and predictability, without which every form of collective action of society would be impossible (Scharpf 1997). Since the industrial revolution, human activities have led to a more rapid rate of environmental change. As the natural sciences are becoming better in predicting the potential future environmental impacts of anthropogenic activities, for example in the case of climate change, institutions will increasingly need to be able to rise to the challenge of incorporating new information and becoming more proactive and progressive in coping with the projected impacts of environmental change. From a social science perspective, it becomes critical to study the conditions under which institutions can stimulate the adaptive capacity of society to deal with the potentially serious and irreversible impacts of environmental change.

Against this background, this paper seeks to address the question: How can the inherent characteristics of institutions to stimulate the adaptive capacity of society from local through to national level be assessed? This question will be applied to the issue of climate change adaptation. This conceptual paper builds on the literature to identify dimensions and criteria and shows how these can be represented in an 'Adaptive Capacity Wheel', an analytical tool to assess the adaptive capacity of institutions (see 2). It presents a research protocol for applying the Adaptive Capacity Wheel (see 3), demonstrates some applications of the Wheel (see 4) and draws conclusions (see 5).

\section{Towards a conceptual framework}

\subsection{An institutional approach to adaptive capacity}

The study of adaptation to climate change is a rapidly evolving field. Society will have to be ready to anticipate and respond to changes that may occur. Consequently its institutions need to support social actors to proactively respond. Because climate change brings unpredictable changes, it calls for institutions that enhance the adaptive capacity of society. This paper develops a generic and flexible framework for assessing the extent to which different characteristics of institutions enable the adaptive capacity of societies.

This section highlights the literature on the subject, the gaps in knowledge, presents a definition of institutional adaptive capacity building on the existing literature, and introduces the Adaptive Capacity Wheel.

\subsection{The literature and its gaps}

There is an explosion in the literature on adaptation to climate change in the last ten years.

This has mostly dealt with the impacts of climate change, vulnerability to the impacts (e.g. Adger 2006) and its criteria and indicators (e.g. Smit and Wandel 2006, Brooks et al. 2005, Eriksen \& Kelly 2007, Moss et al. 2001), and adaptation to the impacts of climate change (e.g. IPCC 2007, O’Brien et al. 2006, Eakin and Luers 2006, Rasmussen et al. 2009, Polsky et al. 2007).

Vulnerability and adaptive capacity are closely linked concepts: adaptive capacity is one of the determinants of vulnerability, in addition to exposure and sensitivity. This paper only focuses on adaptive capacity and not on the other two determinants. In the literature, some 
authors have discussed adaptive capacity specifically (Tol and Yohe 2006, Eriksen and Lind 2009, Pelling et al. 2008, Gallopín 2006), others use the term resilience (Nelson et al. 2007, Folke et al. 2005, Milman and Short 2008). While the articles focus on the adaptive capacity of households (Vincent 2006, Paavola 2008), of local communities (Smit and Wandel 2006, Nelson et al. 2008, cf. Pelling and High 2005, Agrawal \& Perrin 2008, Bapna et. al 2009) and of nations (Haddad 2005, Tol and Yohe 2006); there is little research on assessing institutions on their ability to enhance the adaptive capacity of society (WRR 2006). Furthermore, while much of this literature does mention institutions, they tend to use the word quite loosely (e.g. Yohe and Tol 2002 imply organizations, and to a lesser extent, Agrawal \& Perrin 2008 do so as well). The website of the United Nations Framework Convention on Climate Change lists a number of tools on adaptation, but these do not include an exclusive tool to assess institutions, nor do they provide adequate information on institutions in relation to adaptive capacity in other tools. At the same time, there is a rich history of literature on institutions, governance and management. This paper attempts to bridge the existing literature on institutions, governance and management with the newer literature on adaptation and adaptive capacity to develop a conceptual and methodological framework to assess how institutions can promote the adaptive capacity of societies.

\subsection{Definitions of key term - Institutions}

The Institutions Project of the International Human Dimensions Programme defines institutions as: "systems of rules, decision-making procedures, and programs that give rise to social practices, assign roles to the participants in these practices, and guide interactions among the occupants of the relevant roles" (IDGEC 1999: 14). The rules and roles can be formal governmental policies and informal social patterns of engagement; they can be visible and latent (Arts 2006). In ordinary speech, the word 'institutions' is seen as synonymous with 'organizations'. Although organizations can be seen as formalised patterns of rules and decision making, institutions are not equivalent to organizations, as institutions also refer to underlying ideological values and norms (Zijderveld, 2000, Young 1989, IDGEC 1999).

Institutions are inherently conservative. This is its strength and yet a weakness. Institutions are agreements following long debate, and if these hard-won institutions would not survive until the next day, there would be little point in creating them. Moreover, institutions carry the bias of previous interactions, views and power relations (Klijn \& Koppenjan 2006), a process called institutionalization (Garud et al. 2007, March \& Olsen 1989). Hence, all institutions embed a degree of robustness and resistance to change.

While institutions shape social practices, at the same time those social practices constitute and reproduce institutions (e.g. Giddens 1984). The same agency that sustains the reproduction of structures also makes possible their transformation. Hence, institutions change and can be changed, but it is difficult to do so. It is critical to ask: Do institutions allow society to adapt fast enough to environmental changes? What is needed is a balance between absolute rigidity and total flexibility; where should this balance be if we look at the problem of climate change? Is the 'natural' turnover speed of institutions enough to keep up with these changes, or do we need an extra effort? And if we do, which institutions are the most inhibitive and should be redesigned as a matter of priority?

\subsection{Defining the adaptive capacity of institutions}

Adaptation is distinct from adaptive capacity. The Intergovernmental Panel on Climate Change (IPCC) defines adaptation as: "Adjustment in natural or human systems in response to actual or expected climatic stimuli or their effects, which moderates harm or exploits 
beneficial opportunities" (IPCC 2001: 982, cf. IPCC 2007). The concept of adaptive capacity, influenced by social-ecological systems research (Holling 1986), has been defined by the Millennium Ecosystem Assessment (2006: Glossary, 599) and IPCC (2001: 6, IPCC 2007) as: "The ability of a system to adjust to climate change (including climate variability and extremes) to moderate potential damages, to take advantage of opportunities, or to cope with the consequences". Our literature review did not reveal a definition of institutions that fosters adaptive capacity, although we found many relevant definitions of adaptive capacity in general from the adaptation literature (e.g. Yohe and Tol 2002, Mendelsohn \& Nordhaus 1999, Marlin et al. 2007, Smit et al. 2000, Smit \& Pilifosova 2001) as well as from the organizational change literature (e.g. Lengnick-Hall \& Beck 2005, Weick \& Sutcliffe 2001), and from cybernetics and complexity theories (e.g. Duit \& Galaz 2008).

The next question is: what does adaptive capacity mean, when it is applied to institutions? In identifying criteria for assessing institutional adaptive capacity, the literature on governance (Tompkins \& Adger 2005, Folke et al. 2005, Pierre 2000, Nooteboom 2006, Marks et al. 1996, Klijn \& Koppenjan 2006), international relations (e.g. Young 1991, Malnes 1995, Underdal 1994), organizations (e.g. Argyris 1990, Weick and Sutclilffe 2001) and earth system governance (e.g. Biermann 2007) provides some hints.

Building on the existing definitions and literature, we define adaptive capacity as the inherent characteristics of institutions that empower social actors to respond to short and long-term impacts either through planned measures or through allowing and encouraging creative responses from society both ex ante and ex post. It encompasses:

- The characteristics of institutions (formal and informal; rules, norms and beliefs) that enable society (individuals, organizations and networks) to cope with climate change, and

- The degree to which such institutions allow and encourage actors to change these institutions to cope with climate change.

This implies that institutions should allow actors to learn from new insights and experiences in order to flexibly and creatively 'manage' the expected and the unexpected, while maintaining a degree of identity.

\subsection{Six dimensions of adaptive capacity to assess institutions}

The literature confirms that adaptive capacity is a useful concept to assess institutions, but does not provide a systematic framework to assess the adaptive capacity created by institutions. Our assessment of the literature indicates that (a) a number of the proposed dimensions and criteria could be clustered together as common ideas (e.g. the need for resources); (b) that there is inconsistent understanding of the concept of institutions (see 2.3); (c) that different approaches emphasize different dimensions and criteria (e.g. organizational and international relations literature emphasize leadership, governance literature focuses on good governance); and (d) that most authors emphasize steps to be taken, rather than criteria to be met.

Based on our research, we decided to develop an assessment framework for analyzing the adaptive capacity fostered by institutions. In order to do so, we adopted a seven step methodology. First, we reviewed the existing literature in different disciplines (organization studies, management studies, political science, law) to identify the most important criteria for assessing institutions. Second, we used a computer based collaborative brainstorming session to sort out the different criteria. Similar criteria were evaluated as to whether they added anything new to the discussion or were merely different words for the same criterion. It was important that each criterion should be distinct and not overlapping. Third, in the same 
computer based collaborative session, we clustered the selected criteria under six different dimensions. Fourth, we defined each criterion (see Table 1). Fifth, we tested the application of the criteria in case studies through interviews and observations. Sixth, we applied the criteria through analyses of policy documents to see if the criteria were able to capture all relevant aspects of institutional adaptive capacity. Seventh, we tested the criteria through presentations to Dutch policymakers, three scientific presentations and one hour long presentation and discussion during a side-event at the Conference of the Parties to the United Nations Framework Convention on Climate Change in Copenhagen in December 2009 to see if some specific elements of adaptive capacity were not captured by the total set of criteria adopted. The dimensions and the criteria have accordingly been modified.

The fundamental story line is that institutions that promote adaptive capacity are those institutions that 1) encourage the involvement of a variety of perspectives, actors and solutions; 2) enable social actors to continuously learn and improve their institutions; 3) allow and motivate social actors to adjust their behaviour; 4) can mobilize leadership qualities, 5) can mobilize resources for implementing adaptation measures, and 6) enhance principles of fair governance. These six dimensions have twenty-two criteria. Table 1 presents the dimensions and criteria, defines the criteria, and relates them to the literature. The following paragraphs explain each dimension and criterion in more detail.

Table 1. Adaptive capacity dimensions and criteria and their roots in the literature

\begin{tabular}{|c|c|c|c|}
\hline Dimension & Criterion & Definition & Relation to literature \\
\hline \multirow[t]{4}{*}{ 1. Variety } & $\begin{array}{l}\text { Variety of } \\
\text { problem frames }\end{array}$ & $\begin{array}{l}\text { Room for multiple frames of } \\
\text { references, opinions and problem } \\
\text { definitions }\end{array}$ & $\begin{array}{l}\text { Nooteboom 2006; } \\
\text { Buckley 1968, } \\
\text { Conant \& Ashby } \\
\text { 1970; Pollit and } \\
\text { Bouckaert 2000; } \\
\text { Power } 1999\end{array}$ \\
\hline & $\begin{array}{l}\text { Multi-actor, } \\
\text { multi-level, } \\
\text { multi-sector }\end{array}$ & $\begin{array}{l}\text { Involvement of different actors, } \\
\text { levels and sectors in the governance } \\
\text { process }\end{array}$ & $\begin{array}{l}\text { Pahl-Wostl 2009; } \\
\text { Duit \& Galaz 2008; } \\
\text { Armitage 2008; Folke } \\
\text { et al. } 2005\end{array}$ \\
\hline & $\begin{array}{l}\text { Diversity of } \\
\text { solutions }\end{array}$ & $\begin{array}{l}\text { Availability of a wide range of } \\
\text { different policy options to tackle a } \\
\text { problem }\end{array}$ & $\begin{array}{l}\text { Ostrom 2005; } \\
\text { Verweij \& Thompson } \\
2006\end{array}$ \\
\hline & $\begin{array}{l}\text { Redundancy } \\
\text { (duplication) }\end{array}$ & $\begin{array}{l}\text { Presence of overlapping measures } \\
\text { and back-up systems; not cost- } \\
\text { effective }\end{array}$ & $\begin{array}{l}\text { Weick \& Sutcliffe } \\
2001\end{array}$ \\
\hline \multirow[t]{4}{*}{$\begin{array}{l}\text { 2. Learning } \\
\text { capacity }\end{array}$} & Trust & $\begin{array}{l}\text { Presence of institutional patterns that } \\
\text { promote mutual respect and trust }\end{array}$ & Pelling \& High 2005 \\
\hline & $\begin{array}{l}\text { Single loop } \\
\text { learning }\end{array}$ & $\begin{array}{l}\text { Ability of institutional patterns to } \\
\text { learn from past experiences and } \\
\text { improve their routines }\end{array}$ & $\begin{array}{l}\text { Olson et al. 2004; } \\
\text { Folke et al. 2005; } \\
\text { Carpenter et al. 2001; } \\
\text { Marshal \& Marshal } \\
\text { 2007; Pelling et al. } \\
\text { 2008 }\end{array}$ \\
\hline & $\begin{array}{l}\text { Double loop } \\
\text { learning }\end{array}$ & $\begin{array}{l}\text { Evidence of changes in assumptions } \\
\text { underlying institutional patterns }\end{array}$ & $\begin{array}{l}\text { Argyris 1990; } \\
\text { Ormond } 1999\end{array}$ \\
\hline & Discuss doubts & $\begin{array}{l}\text { Institutional openness towards } \\
\text { uncertainties }\end{array}$ & $\begin{array}{l}\text { Pahl-Wostl 2009; } \\
\text { Weick \& Sutcliffe }\end{array}$ \\
\hline
\end{tabular}




\begin{tabular}{|c|c|c|c|}
\hline & & & 2001 \\
\hline & $\begin{array}{l}\text { Institutional } \\
\text { memory }\end{array}$ & $\begin{array}{l}\text { Institutional provision of monitoring } \\
\text { and evaluation processes of policy } \\
\text { experiences }\end{array}$ & $\begin{array}{l}\text { Ostrom 2005; } \\
\text { Gunderson \& } \\
\text { Holling, 2002 }\end{array}$ \\
\hline \multirow[t]{3}{*}{$\begin{array}{l}\text { 3. Room for } \\
\text { autonomous } \\
\text { change }\end{array}$} & $\begin{array}{l}\text { Continuous } \\
\text { access to } \\
\text { information }\end{array}$ & $\begin{array}{l}\text { Accessibility of data within } \\
\text { institutional memory and early } \\
\text { warning systems to individuals }\end{array}$ & $\begin{array}{l}\text { Folke et al. 2005; } \\
\text { Milman \& Short } \\
\text { 2008; Polsky et al. } \\
2007\end{array}$ \\
\hline & $\begin{array}{l}\text { Act according } \\
\text { to plan }\end{array}$ & $\begin{array}{l}\text { Increasing the ability of individuals } \\
\text { to act by providing plans and scripts } \\
\text { for action, especially in case of } \\
\text { disasters }\end{array}$ & Smit et al. 2000 \\
\hline & $\begin{array}{l}\text { Capacity to } \\
\text { improvise }\end{array}$ & $\begin{array}{l}\text { Increasing the capacity of individuals } \\
\text { to self-organize and innovate - foster } \\
\text { of social capital }\end{array}$ & $\begin{array}{l}\text { Armitage 2005; Folke } \\
\text { et al. 2003 \& 2005; } \\
\text { Pelling \& High 2005; } \\
\text { Smit et al. 2000; } \\
\text { Weick \& Sutcliffe } \\
\text { 2001; Orlikowski } \\
1996\end{array}$ \\
\hline \multirow[t]{3}{*}{$\begin{array}{l}4 . \\
\text { Leadership }\end{array}$} & Visionary & $\begin{array}{l}\text { Room for long-term visions and } \\
\text { reformist leaders }\end{array}$ & $\begin{array}{l}\text { Pielke 1998; } \\
\text { Goldfinsh \& 't Hart } \\
\text { 2003; Young 1991; } \\
\text { DiMaggio } 1988\end{array}$ \\
\hline & Entrepreneurial & $\begin{array}{l}\text { Room for leaders that stimulate } \\
\text { actions and undertakings; leadership } \\
\text { by example }\end{array}$ & $\begin{array}{l}\text { Malnes 1995; } \\
\text { Andersson \& Mol } \\
\text { 2002; Underdal 1994; } \\
\text { Kingdon } 1984\end{array}$ \\
\hline & Collaborative & $\begin{array}{l}\text { Room for leaders who encourage } \\
\text { collaboration between different } \\
\text { actors - adaptive co-management }\end{array}$ & $\begin{array}{l}\text { Folke et al. 2005; } \\
\text { Folke \& Berkes } \\
\text { 2004; Armitage 2005; } \\
\text { Marlin et al. 2007; } \\
\text { Tierney et al. 2006; } \\
\text { Pahl-Wostl et al. } \\
\text { 2007; Young 1991; } \\
\text { Underdal 1994; } \\
\text { Grubb and Gupta } \\
\text { 2000; Anderson and } \\
\text { Mol 2002; Termeer } \\
2009\end{array}$ \\
\hline \multirow[t]{3}{*}{$\begin{array}{l}5 . \\
\text { Resources }\end{array}$} & Authority & $\begin{array}{l}\text { Provision of accepted or legitimate } \\
\text { forms of power; Whether or not } \\
\text { institutional rules are embedded in } \\
\text { constitutional laws }\end{array}$ & Biermann 2007 \\
\hline & $\begin{array}{l}\text { Human } \\
\text { Resources }\end{array}$ & $\begin{array}{l}\text { Availability of expertise, knowledge } \\
\text { and human labour }\end{array}$ & Nelson et al. 2010 \\
\hline & $\begin{array}{l}\text { Financial } \\
\text { Resources }\end{array}$ & $\begin{array}{l}\text { Availability of financial resources to } \\
\text { support policy measures and } \\
\text { financial incentives }\end{array}$ & $\begin{array}{l}\text { Nelson et al. 2010; } \\
\text { Mendelsohn \& } \\
\text { Nordhaus 1999; } \\
\text { Yohe et al. 1996; } \\
\text { Smit et al. 2000; }\end{array}$ \\
\hline
\end{tabular}




\begin{tabular}{|l|l|l|l|}
\hline & & & Yohe \& Tol 2002 \\
\hline $\begin{array}{l}\text { 6. Fair } \\
\text { governance }\end{array}$ & Legitimacy & $\begin{array}{l}\text { Whether there is public support for a } \\
\text { specific institution }\end{array}$ & $\begin{array}{l}\text { Haddad 2005; } \\
\text { Botchway 2001 }\end{array}$ \\
\hline & Equity & $\begin{array}{l}\text { Whether or not institutional rules are } \\
\text { fair }\end{array}$ & $\begin{array}{l}\text { Haddad 2005; } \\
\text { Botchway 2001 }\end{array}$ \\
\hline & Responsiveness & $\begin{array}{l}\text { Whether or not institutional patterns } \\
\text { show response to society }\end{array}$ & Biermann 2007 \\
\hline & Accountability & $\begin{array}{l}\text { Whether or not institutional patterns } \\
\text { provide accountability procedures }\end{array}$ & $\begin{array}{l}\text { Botchway 2001; } \\
\text { Biermann 2007 }\end{array}$ \\
\hline
\end{tabular}

\subsubsection{Variety}

Unstructured problems like climate change embed diverse interests and perspectives. They can only be dealt with within a framework of multiple discourses and solutions, where various actors intervene at different levels of governance. Hence, the assumption is that they can only be addressed through variety. Variety implies that there is no single appropriate ideological framework, no unique optimal policy strategy or set of mutually consistent solutions, but that there are many. It encourages social ingenuity to continuously generate tailor-made solutions. Variety as a criterion can be traced back to the 1960s (Buckley 1968: 495). The 'law' of requisite variety argues that the variety within a system must be at least as great as the environmental variety against which it is attempting to adjust itself (Conant \& Ashby 1970). Variety challenges mainstream policy approaches that focus on clarity, rationality, reductionism, 'performance oriented management' (Pollitt \& Bouckaert 2000), the 'audit society' (Power 1999), efficiency and simplistic solutions (Weick \& Sutcliffe 2001), and opposes free riding. However, variety can also paralyze action, imply suffocating consensus, and negotiated nonsense (Termeer 2007).

Variety requires an institution to envisage future expected and unexpected climate impacts through having a range of proactive strategies, measures and instruments at its disposition "limiting lock-in into a development that precludes future adaptations" (Nooteboom 2006: 23 ). Variety calls for fostering diversity, understanding complication, creating redundancy and resisting the tendency towards simplification and reductionism. Redundancy implies 'more of the same', for example, a back up system for energy production. We argue that institutions embed variety when they (a) allow for a variety of problem frames and solutions; (b) allow for a variety of actors (multi-actor), levels (multi-level) and stakeholders (multi-sector) during the solution formulation process; (c) promote diversity to reach context relevant tailor-made policies; and (d) allow redundancy in the short-term to promote the best long-term solutions.

\subsubsection{Learning capacity}

The concepts of human learning (Ormond 1999), social learning (Wenger 1998), learning capacity and the ability to experiment (Walker et al. 2002) while maintaining all intrinsic critical functions and feedback mechanisms (Olsson et al. 2004) and accommodating perturbations (Adger 2003) are integral to adaptive capacity (Pahl-Wostl 2007). Learning allows for changed understanding based on experiences (Gunderson \& Holling 2002). It also enhances trust between social actors. Adaptive institutions encourage actors to learn; they permit society to question socially embedded ideologies, frames, assumptions, claims, roles, rules and procedures that dominate problem solving. This includes single loop learning (improved routines) and double loop learning (when social actors challenge norms and basic assumptions). Mechanisms that inhibit genuine learning in organizations include defensive 
routines that prevent participants from experiencing embarrassment or threat, and overprotect current frames (Argyris 1990). Redesigning institutions often calls for 'unlearning' past insights, routines, fears and reflexes.

Criteria to assess whether an institution demonstrates learning capacity include allowing and encouraging actors to (a) trust each other; (b) adopt single loop learning, (c) adopt double loop learning; (c) explicitly consider doubts and uncertainties; and (d) stimulate institutional memory.

\subsubsection{Room for autonomous change}

A third quality of adaptive capacity is the ability of an institution to permit social actors to autonomously adjust their behaviour in response to environmental change. This calls for institutions to enable social actors to anticipate possible futures, to take planned preventive measures against important threats, by providing them with the necessary means and information (Polsky et al. 2007). Institutions should also foster the autonomous capacity of individuals and organizations to improvise (Folke et al. 2005, Pelling \& High 2005). This requires institutions to allow social actors to seize opportunities when they present themselves. This is important particularly at lower levels of governance, and especially during a crisis or disaster, since studies reveal that immediate relief efforts are undertaken by 'victims' and not by the government or aid organizations (Tierney et al. 2006). Adaptive institutions enhance this self-help function by encouraging experimentation with and responding to everyday contingencies, breakdowns, and opportunities (Orlikowski 1996), and continuously improvising in short feedback loops to promote a continual update of social practices. Yet, in a complex multi-actor, multi-level, multi-sector and multi-domain setting, short feedback loops between all interdependent units may make cooperation difficult.

Criteria to assess the room for autonomous change include understanding whether institutions ensure that actors (a) have continuous access to information, (b) are capable of acting according to plan and (c) have the capability to improvise.

\subsubsection{Leadership}

A fourth criterion is leadership, without which society is often unable to respond to the longterm, large-scale challenges that affect humanity. Leadership is a driver for change, showing a direction, motivating others to follow. The management literature differentiates between autonomous (Wallis \& Dollery 1997), entrepreneurial (Andersson \& Mol 2002), reformist (Goldfinch \& 't Hart, 2003) and institutional leadership (DiMaggio 1988), and policy entrepreneurs (Kingdon 1984). The institutions literature refers to structural, entrepreneurial and intellectual leadership (Young 1991), coercive, instrumental and unilateral leadership (Underdal 1994), sticks and carrots, problem solving and directional leadership (Malnes 1995) and structural, instrumental and directional leadership (Grubb \& Gupta 2000). Leadership may sometimes conflict with variety; but good leaders are able to provide space for variety.

Our focus is on how institutions encourage leaders to emerge and reshape the very institutions themselves. Criteria to evaluate leadership include whether institutions encourage the rise of (a) visionary (which includes elements of reformist, intellectual, and sticks and carrots leadership), (b) entrepreneurial (which includes elements of leadership by example, designing tools to engage the market, unilateral and directional leadership), and (c) collaborative leadership (which is also referred to as instrumental leadership in the literature). We have 
omitted structural and coercive leadership on the basis of the argument that in democratic countries leadership needs to be legitimate and inspirational, rather than coercive.

\subsubsection{Resources}

The effectiveness of institutions often depends on their ability to generate resources (Yohe et al. 1996, Mendelsohn \& Nordhaus 1999, Nelson et al. 2010). Institutions should be able to generate sufficient resources/incentives for actors to change norms and rules, implement those changed norms and rules and to live up to them (Biermann 2007). Such resources can include financial, political, human, legal, and technological resources. Criteria include whether institutions encourage (a) authority (legal and political mandate), (b) human (knowledge, skills and labour), and (c) financial (including access to technological) resources. Clearly, the context within which institutions exist will also have a major influence on whether such institutions are able to raise resources.

\subsubsection{Fair governance}

Lastly, the assumption is that institutions support adaptive capacity when they meet fair governance criteria. Since we emphasise redundancy over cost-effectiveness, we have chosen fair governance in preference to the dominant phrase of good governance (e.g. Botchway 2001). Of course, fairness also implies that resources should not be squandered indiscriminately. An appropriate balance needs to be found between effectiveness and efficiency, as innovation processes are notoriously inefficient (Mintzberg 1989) and should be allowed to be inefficient in order to take place at all. Maximum efficiency is only possible in a stable and certain environment and, therefore, it cannot be a first priority when dealing with climate change. Fair governance furthermore includes legitimate policy-making that is accepted by members of society, equitable policy processes and outcomes that take account of unequal circumstances in society (Haddad 2005), responsive processes that show a high degree of transparency and are able to respond to different voices in society (Biermann 2007), and clear accountability procedures that assign responsibilities to different parties (Botchway 2001). Therefore, the criteria for fair governance include: (a) legitimacy, (b) equity, (c) responsiveness and (d) accountability.

\subsection{The Adaptive Capacity Wheel}


In order to structure the information and to be able to communicate it more clearly, an Adaptive Capacity Wheel was designed in 2007 (see Figure 1). The inner circle shows adaptive capacity as a whole, the middle circle shows the dimensions and the outer-circle shows the criteria. Below the wheel, we present a table showing a colour and scoring system that could be applied to this wheel. By applying colours to distinguish between high (green: quantitative value +2 ) to low (red: quantitative value -2 ) adaptive capacity, this wheel may be used to both assess and inform social actors about how their institutions influence different aspects of adaptive capacity and where there may be room for discussion and reform. This wheel is to some extent similar to the Vulnerability Scoping Diagram of Polsky et al. (2007), except that it focuses and expands on the Adaptive Capacity component and is limited to institutions.

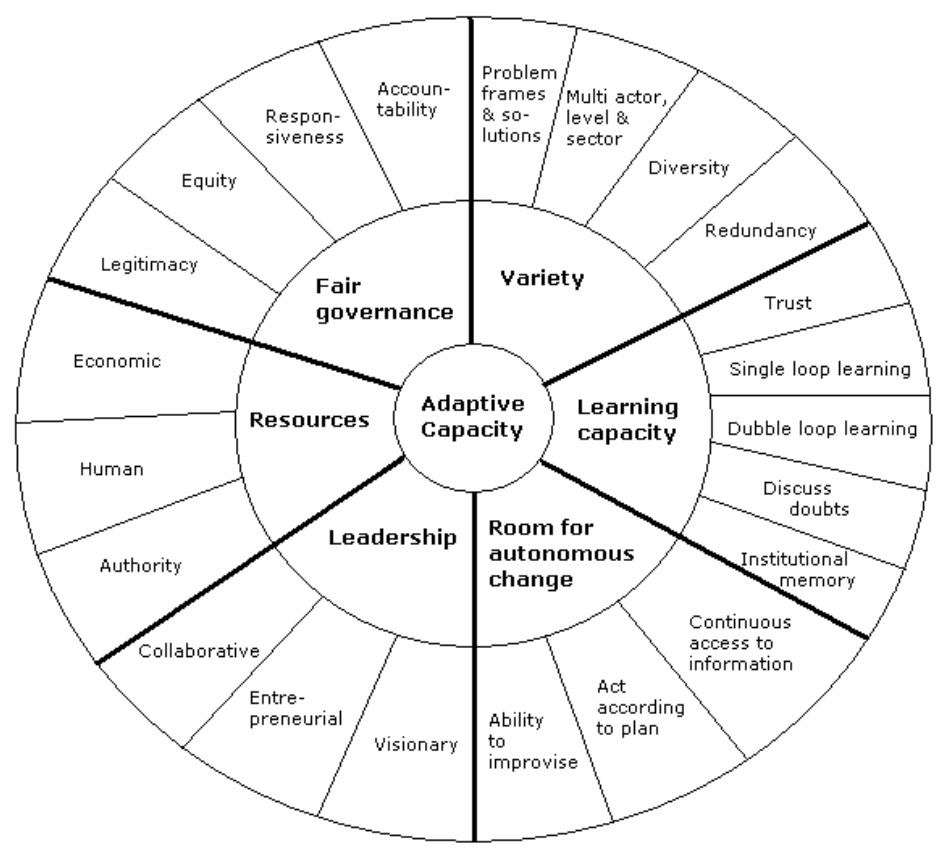

\begin{tabular}{|l|c|c|}
\hline $\begin{array}{l}\text { Effect of institution on } \\
\text { adaptive capacity }\end{array}$ & Score & $\begin{array}{l}\text { Aggregated scores for dimensions } \\
\text { and adaptive capacity as a whole }\end{array}$ \\
\hline & & 1,01 to 2,00 \\
\hline Positive effect & 2 & 0,01 to 1,00 \\
\hline Slightly positive effect & 1 & 0 \\
\hline Neutral or no effect & 0 & $-0,01$ to $-1,00$ \\
\hline Slightly negative effect & -1 & $-1,01$ to $-2,00$ \\
\hline Negative effect & -2 &
\end{tabular}

Figure 1. The Adaptive Capacity Wheel and scoring scheme

\subsection{Assessing the criteria}


The identification of the dimensions and their underlying criteria appear to be relatively comprehensive. Hence, this conceptual framework consisting of the six dimensions and twenty-two criteria should be seen as an analytical structuring tool to assist researchers as well as policy makers in their efforts to understand, assess and increase the ability of institutions to foster the adaptive capacity of society.

However, there are some key points to keep in mind. First, even if an institution appears to create adaptive capacity, this does not automatically mean that society will use this capacity and be able to successfully adapt; merely that the institution provides a higher likelihood of allowing for adaptation. Second, the dimensions and criteria are not independent of each other. They can reinforce each other: For example, adequate resources and fair governance can reinforce all the others. There can be tensions between the criteria as well: For example, between diversity of solutions and act according to plan, or between strong leadership and high variety. Third, some criteria may make others less relevant. For example, if there is sufficient entrepreneurial leadership, this may displace the need for visionary leadership. Finally, the dimensions and criteria are not independent of context. This means that the specific application of the wheel to a specific problem may determine whether some of these dimensions are less or more important. This will imply giving different weights to the different criteria and / or dimensions in a specific context. For example, in some cases diversity of solutions might be considered a more important characteristic of institutions to increase the adaptive capacity of society than the ability to act according to a plan; however, in other situations the ability to act according to plan might be more crucial.

This implies that the wheel cannot be 'objectively' applied; the criteria are not additive in the sense that values given to each criterion can be simply added; it will always be subject to expert judgement and good interpretation. The evaluator will have to interpret the information collected in relation to the dimensions and criteria and draw lessons from the assessment to increase the capacity to adapt in a specific context. For such a qualitative tool to have scientific relevance, it is imperative that it is transparent and that its application by different researchers to the same institution(s) should lead to consistent results. Hence, it is important that there is a structured methodology for applying this wheel.

\section{A protocol for applying the Adaptive Capacity Wheel}

\subsection{An outline}

Where expert judgement is needed, a good research protocol needs to be made. This section highlights the five steps in such a protocol: Preparing for the research; collecting the data; analyzing the data; interpreting the data; and presenting the data.

\subsection{Preparing for the research}

In the first step, the researcher needs to clearly understand and internalize the meaning of each dimension and criterion. Then he/she needs to identify a clear research focus: which institution or institutional context is to be the focus of attention for which period and why?

\subsection{Collecting the data}

In the second step, data are collected for each criterion. Data can be collected in different ways, e.g. through interviews, observations and/ or (policy) document analysis, depending on the institutional context that is being researched. For example, data on informal rules like norms and values and implementation challenges could be collected through interviews and data on formal rules like governmental policies could be collected through document analysis. 
Developing a list of questions can help secure information regarding the criteria. In the case of interviews, we argue that there are essentially six groups of questions - one on each dimension - following a warm-up question and a concluding question. ${ }^{1}$ The questions should be open, with possible follow-up questions to elucidate the specific nature of the answer especially in relation to the definitions provided in Table 1. The questions should, as far as possible, not use technical language: i.e. they should not say: Is directional leadership a strong point of the local institution; but rather: how would you characterise the nature of the leadership shown or stimulated by the existing rule? The warm-up and concluding questions should try and ascertain if some important element has been missed out in the discussions and if there are reinforcing or contradictory ideas and forces within the institutional system in a specific context. For observations a similar technique could be used, with the difference that the researcher should see if the dimension are covering every relevant aspect. In the case of a document analysis, a more comprehensive list of questions (for example, one on each criterion) could be useful, however, those should be well defined and delineated to keep a clear focus while studying the texts. The stakeholder answers and/or the observations and/or the document analysis must be registered in a formal background document without any additional interpretation.

\subsection{Analyzing the data}

The third step consists of analyzing the data collected to score each criterion of adaptive capacity (see table under Figure 1). It is necessary to have different researchers independently score the background data and then discuss the difference of opinion, if any, on a specific criterion. This helps to ensure transparency as well as robust results. All researchers should keep a record of the arguments why a particular criterion has been scored in a particular way.

There are some optional further steps: If needed, it is possible to generate aggregated scores for adaptive capacity as a whole, by adding the scores of each criterion and then dividing by the number of criterion per dimension, and then adding the scores for each dimension and then dividing by 6 (the number of dimensions). These steps are only useful if the researcher wishes to compare a large number of different institutions (see, for example, Table 2); but such an aggregation method needs to be used with caution since not all criteria are additive.

\subsection{Interpreting the data}

The fourth step is to translate the information collected into a story - a story that communicates the strengths and weaknesses of a specific institution or institutional context in terms of adaptive capacity. In this step, the scores are interpreted to give them meaning in their context. For example, what does a '-1' score on learning capacity mean for the institution that is being researched; and what can be done to improve this dimension of adaptive capacity? Data interpretation also includes explaining (inter)dependencies between criteria and/or dimensions; and tensions between criteria and/or dimensions; which criterion appears to be in conflict with another criterion in a specific situation and why? Finally the researcher needs to draw conclusions on what the interpretations imply about the ability of a specific institution to promote the adaptive capacity of society; and what can be done to improve the adaptive capacity of the institution.

\footnotetext{
${ }^{1}$ An MSc student has applied the Adaptive Capacity Wheel to South Korea using a detailed closed questionnaire with 22 questions on each sub-criteria. He was able to encourage his respondents to give him answers for each criteria, and this demonstrates that the alternative approach can also work; however, he was only able to generate quantitative results - as there was no room to secure quantitative results in a questionnaire of 22 questions.
} 


\subsection{Presenting and communicating the data}
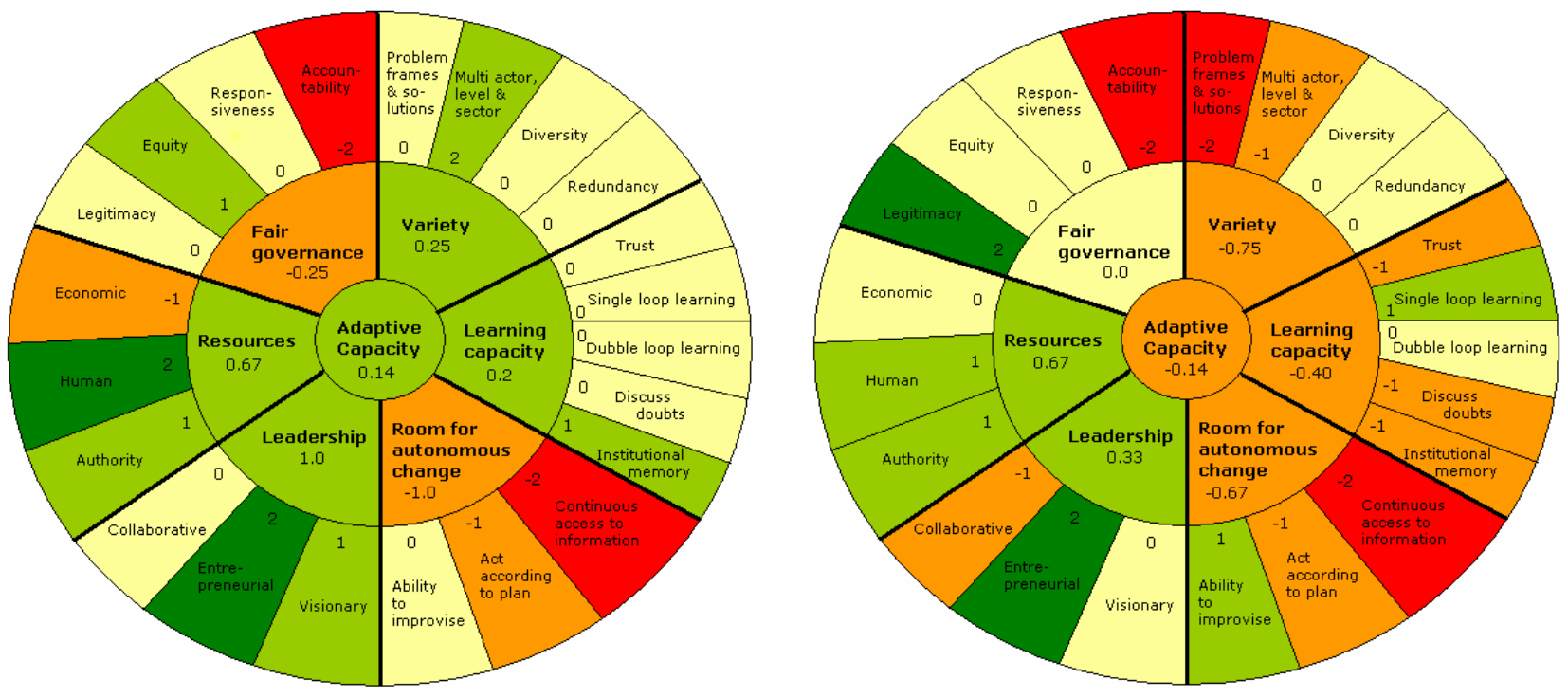

Figure 2. Application of the Adaptive Capacity wheel to Delft (left) and Zaandam (right).

\subsection{Case study with qualitative research}

In order to demonstrate the usability of this wheel in qualitative research, this section briefly elaborates on a case study in which the Adaptive Capacity Wheel was used to assess the performance of institutions in the Dutch urbanized municipalities of Delft and Zaandam with respect to sharing responsibilities for rainfall and ground water management between residents and government actors. Several studies indicate that sharing responsibilities for local water management will become problematic under the influence of climate change (e.g. Huber 2004, Naess et al. 2005, Koch et al. 2007). Hence, our case study examined whether the institutions (formal rules, informal norms and customs, and actual practises) concerning the division of municipal and individual responsibility in local water management encourage adaptive capacity.

In this case study, we systematically implemented the research protocol. Data was collected through in-depth interviews with nineteen stakeholders involved in the municipalities' local water management. In the data analysis process, we used the scoring system, assigned scores to criteria based on the interviews (see Figure 2) and clarified the underlying arguments. In the data interpretation process, we interpreted the scores on criteria in the context of both municipalities. For example, it appeared that in both regions, indistinct accountability procedures for causing and solving water problems imply that residents often do not act in accordance to the roles assigned to them in the law. This behaviour can be explained by the fact that municipalities are urbanized and that residents often have no information on, or interest in, ground water flows. The complex structure of cities calls for a centralized management of responsibilities and accountability. However, such a top-down management 
approach of governmental bodies hampers variety, learning capacity and the room for autonomous change in some ways. This analysis shows that in cities, there might be a tension between regulating responsibilities between actors and adopting a multi-level, collaborative management approach. In the data presentation and communication process, we have used the traffic light colours to communicate the results to policymakers to discuss and test the results (see Figure 2). For details on this case study see Bergsma et al. (2009).

In qualitative research like the case studies, the Adaptive Capacity Wheel provides information about the performance of institutions. The results of the Adaptive Capacity Wheel can be the starting point of a discussion on how institutions can enhance the adaptive capacity of society in a particular context. The colours in the wheel immediately identify areas in which the institutions do not encourage adaptive capacity, and the explanation of the researcher can help to better understand why institutions are not functioning well in those areas and what can be done to improve their impact on the adaptive capacity of society.

\subsection{Content analysis with semi quantitative research}

The Adaptive Capacity Wheel can also be applied to assess policies and regulations. Where one is comparing many institutions, it may seem more relevant to undertake an additional step and aggregate the information into single quantitative scores. We have argued that the criteria are not additive and, hence, this step should be undertaken with caution. This implies that in addition to the steps taken in the previous case study, the optional fifth step under Analyzing the Data should be undertaken (under 3.3). One can aggregate the information on the different criteria into one value and again aggregate the data on the six dimensions into one score on a specific institutions' ability to promote the adaptive capacity of societies; however, with increasing aggregation, detail is lost. It is thus recommended to never use the aggregate tool without the separate Adaptive Capacity Wheels backing such an aggregation.

We have applied this technique in an assessment of the formal Dutch institutions (governmental policies and regulations) ability to enhance the adaptive capacity of society. We focused on four sectors (nature, water, agriculture and spatial planning) and policies that specifically address climate change adaptation. In data collection, we collected data on each criterion by reading all the policy documents and conducting a content analysis. In the data analysis, we undertook the steps mentioned in section 3 and, since a content analysis can often lie in the eye of the beholder, the content analysis was double checked in three rounds by three different researchers, individually and then jointly. We kept a record of why we scored a criterion in a particular way in order to make the arguments transparent. Quantitative scores were assigned to the different criteria, which were then tallied to get a single value for each institution. The third step consisted of interpreting the results by comparing the scores. The results, for example, demonstrate that the nature protection arrangements foster the least adaptive capacity, while those focusing on water score quite well in the Netherlands. Table 2 below presents the results of the assessment, which are elaborated in a separate paper (Klostermann et al. 2009).

Both the assessment of formal and informal institutions in two Dutch municipalities and the assessment of formal Dutch national institutions are qualitative in the sense that researchers interpret data (interviews and policy documents) to 'score' criteria. The difference is that the results in the case study are presented in a qualitative way, and allow for extended explanation 
by the researcher, while the results of the policy analysis are presented quantitatively (by numbers) to facilitate comparison.

Table 2. Application of the Adaptive Capacity Wheel to a comparative content analysis

\begin{tabular}{|l|l||c|}
\hline Issue & Instrument/institution & $\begin{array}{c}\text { Score } \\
\text { on AC }\end{array}$ \\
\hline Climate /general & & \\
\hline & National Adaptation Strategy: make space for climate! & 0.85 \\
\hline & Strategy National Safety and National Risk Assessment & 0.64 \\
\hline Nature & & \\
\hline & Ecological main structure & 0.14 \\
\hline & Law for the Protection of Nature & -0.21 \\
\hline & Flora and Fauna Law & -0.44 \\
\hline Water & & \\
\hline & National Agreement on Water & 1.09 \\
\hline & National Water Plan 2008 & 1.27 \\
\hline & Policy Guideline Large Rivers & 0.79 \\
\hline & Water Law & 0.98 \\
\hline & Water Test & 0.49 \\
\hline & & 1.00 \\
\hline Agriculture & Agenda for a Living Countryside - Multi-year \\
\hline & programme 2007-2013 & 1.19 \\
\hline & Law on Land Use in Rural Areas & 0.61 \\
\hline & New agrarian insurances & 0.64 \\
\hline & & 0.85 \\
\hline Spatial planning & National Spatial Strategy & 0.64 \\
\hline & Spatial Planning Act & \\
\hline & Strategic Environmental Assessment & \\
\hline & & \\
\hline
\end{tabular}

\section{Conclusion}

This paper elaborates on a method to assess the inherent characteristics of institutions to promote the capacity of society to adapt to climate change. Institutions are not defined as actors (organizations); they are the social rules that both constrain and empower social actors. Institutions are both the result of human interaction and they in turn shape human action.

Based on the literature, field experiences and brainstorming, this paper has generated six dimensions, each with its own criteria, to assess if institutions are designed to stimulate the adaptive capacity of society. This information is presented in the Adaptive Capacity Wheel.

There are clear advantages to using the Adaptive Capacity Wheel. First, its elements provide a comprehensive idea of the dimensions relevant for assessing the adaptive capacity of society through its institutions. In all our applications, we have asked our participants if we have 
overlooked a key dimension, which is also perhaps missing in the literature. In general, we may have erred more in being too comprehensive than under-comprehensive. However, the Wheel allows for expansion and inclusion of new ideas in the future, if that is needed.

Second, colours have been used to represent the results of the assessment. We have two variations: a variation in shades of grey (not applied in this article), which is entirely neutral in terms of its message; and a variation that builds on the traffic-light colours which is more judgmental, but is also more communicative.

Third, the Adaptive Capacity Wheel can be used to generate quantitative results. Quantitative results can be used to rank, for example, which institutions score better and which worse on an adaptive capacity scale. The aggregated picture can draw attention to a set of institutions that is working in a specific field. For example, our document analysis shows that in the nature sector, there is probably a common underlying paradigm that is responsible for the relatively low score assigned to these institutions' ability to stimulate the adaptive capacity of society. The application of the Adaptive Capacity Wheel allows us to see if some institutions promote adaptive capacity (e.g. several water arrangements) or not (e.g. the nature arrangements in the Netherlands). This shows which institutions are the most inhibitive and are likely to need redesign. Although such a quantitative analysis may reduce complex information into a simple format and be useful for a ranking process, it may also reduce the information to something relatively meaningless and too aggregated. If the institutions in the nature sector are really inhibiting adaptation, this will become clearer when the results of the analysis with the adaptive capacity wheel are discussed in detail with the relevant stakeholders.

The Adaptive Capacity Wheel also has some interesting paradoxes: for example, we hinted before at the paradox between variety and leadership: strong leadership may automatically lead to less variety and weak leadership may have the advantage that a lot of variety is developed in society. Such paradoxes in the Wheel reflect paradoxes in social reality itself. Understanding adaptive capacity may call for expert judgements regarding how to deal with the overlaps and contradictions between criteria.

Other key questions include: How objective is the evaluation? Are the equal shares for each dimension and criteria in the Wheel reflective of equal weights? In response to the first question, a comprehensive coding system allows for enhanced transparency of the evaluation; even though there will always be a subjective element in it. In response to the second question, we have assigned equal weights to the dimensions and criteria in our applications. However, in a specific context, one dimension or criterion might be more important than another, and explaining these kinds of contextual varieties is an important step in applying wheel. This does not stop future applications of the wheel from experimenting with assigning weights in specific contexts in a more rationalized way; and on comparing how adaptive capacity improves or changes over time.

In presentations to policymakers and scientists, the Adaptive Capacity Wheel has been viewed as a useful qualitative tool for assessing institutions, for comparing and contrasting them and in promoting self-reflection among policymakers and other social actors. Comparing the results of policy sectors in an aggregated way may stimulate cross-sectoral learning on how institutions in each sector are built. The Adaptive Capacity Wheel furthermore need not be limited to assessing the adaptive capacity to responding to the 
problem of climate change, but could be expanded for use with respect assessing the capacity to deal with other long-term unstructured problems.

\section{Acknowledgements}

This paper is part of ongoing research entitled: 'IC12: Institutions for Adaptation: The Capacity and Ability of the Dutch Institutional Framework to Adapt to Climate Change', which is funded by the Netherlands BSIK-Programme Climate changes Spatial Planning $(\mathrm{CcSP})^{2}$.

\section{References:}

Adger, N., 2003. Social aspects of adaptive capacity, in: Smith, J., Klein, J., Huq. S. (Eds), Climate change, adaptive capacity and development. Imperial College Press, London, pp. 29-49.

Adger, N., 2006. Vulnerability. Global Environmental Change 16, 268-281.

Agrawal, A., 2008. The Role of Local Institutions in Adaptation to Climate Change. The World Bank, Washington, DC.

Andersson, M., Mol, A.P.J., 2002. The Netherlands in the UNFCCC Process - Leadership between Ambition and Reality. International Environmental Agreements 2, 49-68.

Argyris, C., 1990. Overcoming organizational defences: Facilitating organizational learning. Allyn and Bacon, Boston.

Armitage, D., 2008. Governance and the commons in a multi-level world. International Journal of the Commons 2(1), 7-32.

Arts, B., 2006. Forests, institutions, discourses. Wageningen Universiteit, Wageningen.

Bapna, M. , McGray, H., Mock, G., Withey, L., 2009. Enabling Adaptation: Priorities for Supporting the Rural Poor in a Changing Climate. Available online at http://pdf.wri.org/issue_brief_enabling_adaptation.pdf

Bergsma, E., Gupta, J., Jong, P., 2009. IC12 Institutions for Climate Change - case study on individual responsibility in adaptive capacity. Working Document 7, Report number W09/10, Institute for Environmental Studies, Amsterdam.

Biermann, F., 2007. 'Earth system governance' as a crosscutting theme of global change research. Global Environmental Change 17, 326-337.

Botchway, F.N., 2001. Good Governance: the Old, the New, the Principle, and the Elements. Florida Journal of International Law 13(2), 159-210.

Brooks, N., Adger, W.N., Kelly, P.M., 2005. The determinants of vulnerability and adaptive capacity at the national level and the implications for adaptation. Global Environmental Change 15, 151-163.

Buckley, W. (Ed), 1968. Modern Systems research for the behavioural sciences. Aldine, Chigago.

Carpenter, S., Walker, B., Anderies, J. M., \& Abel, N., 2001. From Metaphor to Measurement: Resilience of What to What? Ecosystems 4(8), 765-781.

\footnotetext{
${ }^{2}$ www.climatechangesspatialplanning.nl
} 
Conant, R.C., Ashby, R.W., 1970. Every good regulator of a system must be a model of that system. International Journal of Systems Science 1(2), 89-97.

DiMaggio, P.J., 1988. Interest and Agency in Institutional Theory, in: Zucker, L.G. (ed.), Institutional Patterns and Organizations. Ballinger, Cambridge.

Downing, T.E., Watts, M.J., Bohle H.G., 1995. Climate change and food insecurity: Towards a sociology and geography of vulnerability, in: Downing, T.E., (Ed.), Climate Change and World Food Security. Springer, Berlin, pp. 183-206.

Duit A., Galaz, V., 2008. Governance and complexity - emerging issues for governance theory. Governance: an international journal of policy, administration and institutions 21(3), 311-335.

Eakin, H., Luers, A.L., 2006. Assessing the Vulnerability of Social-Environmental Systems., Ann. Rev. Environmental Resources 31, 365-94.

Eriksen, S., Lind, J., 2009. Adaptation as a Political Process: Adjustment to Drought and Conflict in Kenya's Drylands. Environmental Management 43, 817-843.

Eriksen, S.H., Kelly, P.M., 2007. Developing credible vulnerability indicators for climate adaptation policy assessment. Mitigation and Adaptation Strategies for Global Change 12, 495-524.

Folke, C., Colding, J., Berkes, F., 2003. Synthesis: building resilience and adaptive capacity in social-ecological systems, in: Berkes, F., Colding, J., Folke, C. (Ed.), Navigating social-ecological systems. Cambridge University Press, Cambridge, UK, pp 252-387.

Folke, C., Hahn, T., Olsson, P., Norberg, J., 2005. Adaptive governance of social-ecological systems. Annual Review of Environment and Resources 30(1), 441-473.

Gallopín, G.C., 2006. Linkages between vulnerability, resilience and adaptive capacity. Global Environmental Change 16, 293-303.

Garud, R., Hardy, C., Maguire, S., 2007. Institutional Entrepreneurship as Embedded Agency: An Introduction to the Special Issue. Organization Studies 28(7), 957-969.

Giddens, A., 1984. The Constitution of Society. Polity Press, Cambridge.

Gilbert, A.J., 2006. Coevolution in complex networks. An analysis of socio-natural interactions for wetlands management. VU Vrije Universiteit, Print Partners Ipskamp B.V., Enschede.

Goldfinch, S., Hart. P. 't, 2003. Leadership and institutional reform: engineering macroeconomic policy change in Australia. Governance 6(2), 235-270.

Grubb, M., Gupta, J., 2000. Towards a Theoretical Analysis of Leadership, in: Gupta, J., Grubb, M. (eds.), Climate Change and European Leadership: A Sustainable Role for Europe. Kluwer Academic Publishers, Dordrecht, pp.15-24.

Gunderson, L. H., Holling, C.S., 2002. Panarchy: Understanding Transformations In Human And Natural Systems. Washington: Island Press.

Gupta, J., Dellapenna, J., 2009. The Challenges for the Twenty First Century: A Critical Approach, in: Dellapenna, J., Gupta J. (eds.), The Evolution of the Law and Politics of Water. Springer Verlag, Dordrecht, pp. 391-410.

Haddad, B., 2005. Ranking the adaptive capacity of nations to climate change when sociopolitical goals are explicit. Global Environmental Change 15, 165-176. 
Holling, C.S., 1986. The resilience of terrestrial ecosystems: local surprise and global change, in: Clark, W.C., Munn R.E. (eds.), Sustainable development of the biosphere. Cambridge University Press, Cambridge, pp. 292-317.

Huber M., 2004. Insurability and Regulatory Reform: Is the English Flood Insurance Regime Able to Adapt to Climate Change? The Geneva Papers on Risk and Insurance 29(2) 169182.

IDGEC Scientific Planning Committee, 1999. Institutional Dimensions of Global Environmental Change. IHDP Report No. 9, Bonn.

IPCC, 2001. Climate Change 2001: Impacts, Adaptation and Vulnerability, Contribution of Working Group II to the Third Assessment Report of the Intergovernmental Panel on Climate Change, in McCarthy, J.J., Canziani, O.F., Leary, N.A., Dokken, D.J., White, K.S. (eds). Cambridge University Press, Cambridge.

IPCC, 2007. Climate Change 2007: Impacts, Adaptation, and Vulnerability, Contribution of Working Group II to the Fourth Assessment Report of the Intergovernmental Panel on Climate Change, , in McCarthy, J.J., Canziani, O.F., Leary, N.A., Dokken, D.J., White, K.S. (eds). Cambridge University Press, Cambridge.

Kingdon, J. W., 1984. Agendas, Alternatives, and Public Policies. Harper Collins, New York.

Klijn, E.H., Koppenjan, J.F.M., 2006. Governing Policy Networks: a Network Perspective on Decision Making in Network Society, in: G. Morcol (Ed.), Handbook of decision-making. CRC Press, New York, 169-187.

Klostermann, J., Gupta, J., Termeer, K., Meijerink, S., Van den Brink, M., Nooteboom, S., Jong, P., Bergsma, E., Biesbroek, R., 2009. How to assess the adaptive capacity of legislation and policies. Paper for the 2009 Amsterdam Conference on the Human Dimensions of Global Environmental Change - Earth System Governance. People. Places and the Planet, 2-4 December 2009, Amsterdam.

Koch, I.C., Vogel, C., Patel, Z., 2007. "Institutional dynamics and climate change adaptation in South Africa. Mitigation and Adaptation Strategies for Global Change 12, 1323-1339.

Lengnick-Hall, C.A., Beck, T.E., 2005. Adaptive Fit Versus Robust Transformation: How Organizations Respond to Environmental Change. Journal of Management 31(5), 738757.

Malnes R., 1995. 'Leader' and 'Entrepreneur' in International Negotiations: a conceptual analysis. European Journal of International Relations 1(1), 87-112.

March, J.G., Olsen, J.P., 1989. Rediscovering Institutions. Free Press, New York.

Marks, G., Hooghe, L., Blank, K., 1996. European Integration from the 1980s: State-centric v. Multi-Level Governance. Journal of Common Market Studies 34(3), 341-378.

Marlin, A., Olsen, L., Bruce, D., Ollerhead, J., Singh, K., Heckman, J., Walters, B., Meadus, D., Hanson, A., 2007. Examining Community Adaptive Capacity to Address Climate Change, Sea Level Rise, and Salt Marsh Restoration in Maritime Canada. Submitted to the Climate Change Impacts and Adaptations Program, Mount Allison Coastal Wetlands Institute and the Rural and Small Town Programme, Mount Allison University, Sackville.

Marshall, N.A., Marshall, P.A., 2007. Conceptualising and operationalising social resilience within commercial fisheries in Northern Australia. Ecology and Society 12(1), [online] URL: http://www.ecologyandsociety.org/vol12/iss1/art1/ 
Mendelsohn, R., Nordhaus, W., 1999. The Impact of Global Warming on Agriculture: A Ricardian Analysis: Reply. American Economic Review 89(4), 1046-1048.

Millennium Ecosystem Assessment, 2006. Ecosystems and Human Well-Being. Working Group Assessment Reports, five volumes, Island Press, Washington, D.C. Online available at www.maweb.org.

Milman, A., Short, A., 2008. Incorporating Resilience into Sustainability Indicators: An Example for the Urban Water Sector. Global Environmental Change 18, 758-767.

Mintzberg, H., 1989. Mintzberg on management: inside our strange world of organizations. The Free Press, New York, Collier Macmillan, London.

Moss, R.H., Brenkert, A.L., Malone, E.L. 2001. Vulnerability to Climate Change: A Quantitative Approach. Technical Report PNNL-SA-33642, 2001.

Naess, L.A., Bang, G., Eriksen, S., Vevatne, J., 2005. Institutional adaptation to climate change: Flood responses at the municipal level in Norway. Global Environ-mental Change $15,125-138$.

Nelson, D.R., Adger, W.N., Brown, K., 2007. Adaptation to Environmental Change: Contributions of a Resilience Framework. Ann. Rev. Environmental Resources 32, 395419.

Nelson, R., Howden, M., Smith, M.S., 2008. Using adaptive governance to rethink the way science supports Australian drought policy. Environmental Science \& Policy 11, 588-601.

Nooteboom, S.G., 2006. Adaptive Networks. The governance for Sustainable Development, Eburon, Delft.

Nelson, R., Kokic, P., Crimp, S., Martin, P., Meinke, H., Howden, S.M., de Voil, P., Nidumolu, U., 2010. The vulnerability of Australian rural communities to climate variability and change: Part II - Integrating impacts with adaptive capacity. Environmental Science \& Policy 13, 18-27.

Nooteboom, S., 2006. Adaptive networks, the governance for sustainable development. Delft: Eburon.

O’Brien, K., Eriksen, S., Sygna, L., Naess, L.O., 2006. Questioning Complacency: Climate Change Impacts, Vulnerability and Adaptation in Norway. Ambio 35(2), 50-56.

Olsson, P., Folke, C., Berkes, F., 2004. Adaptive Co-Management for Building Resilience in Social-Ecological Systems. Environmental Management 34, 75-90.

Orlikowski, W.J., 1996. Improvising organizational transformation overtime: a situated change perspective. Information Systems Research 7(1), 63-92.

Ormond, J.E., 1999. Human learning (3rd ed). Prentice-Hall, Upper Saddle River.

Ostrom, E., 2005. Understanding institutional diversity. Princeton University Press, Princeton, New Jersey

Paavola, J., 2008. Livelihoods, vulnerability and adaptation to climate change in Morogoro, Tanzania. Environmental Science \& Policy 11, 642-654.

Pahl-Wostl, C., 2009. A conceptual framework for analysing adaptive capacity and multilevel learning processes in resource governance regimes. Global Environmental Change $19,354-365$. 
Pahl-Wostl, C., Craps, M., Dewulf, A., Mostert, E., Tabara, D., Taillieu, T., 2007. Social learning and water resources management. Ecology and Society 12(2), 5.

Pelling, M., High, C., 2005. Understanding Adaptation: What Social Capital Offer Assessments of Adaptive Capacity. Global Environmental Change 15, 308-319.

Pelling, M., High, C., Dearing, J., Smith, D., 2008. Shadow spaces for social learning: a Relational Understanding of adaptive capacity to climate change within organizations. Environment and Planning A 40, 867-884.

Pielke, R.A., 1998. Rethinking the role of adaptation in climate policy. In: Global Environmental Change, Vol. 8, No. 2, pp. 159-170

Pierre, J. (ed), 2000. Debating Governance. Oxford University Press, Oxford.

Pollit C., Bouckaert, G., 2000. Public Management Reform: A Comparative Analysis. Oxford University Press, Oxford.

Polsky, C., Neff, R., Yarnal, B., 2007. Building comparable global change vulnerability assessments: The Vulnerability Scoping Diagram. Global Environmental Change 17, 472485.

Power, M., 1999. The Audit Society: Rituals of Verification. Oxford University Press, Oxford.

Rasmussen, K., May, W., Birk, T., Mataki, M., Mertz, O., Yee, D., 2009. Climate Change on three Polynesian outliers in the Solomon Islands: Impacts, Vulnerability and Adaptation. Danish Journal of Geography 109(1), 1-13.

Scharpf, F.W., 1997. Games Real Actors Play. Actor-centered Institutionalism in Policy Research. Westview Press, Boulder.

Smit, B., Wandel, J., 2006. Adaptation, Adaptive Capacity and Vulnerability. Global Environmental Change 16, 282-292.

Smit, B., Pilifosova, O., 2001. Adaptation to Climate Change in the Context of Sustainable Development and Equity, in: McCarthy, J.J., Canzianni, O.F., Leary, N.A. Dokken, D.J., White, K.S. (eds.), Climate Change 2001: Impacts, Adaptation, and Vulnerability Contribution of Working Group II to the Third Assessment Report of the Intergovernmental Panel on Climate Change. Cambridge University Press, Cambridge, pp. 876-912.

Smit, B., Burton, I., Kleinand, R., Wandel, J., 2000. An anatomy of adaptation to climate change and variability. Climate change 45, 223-251.

Termeer, C.J.A.M., 2007. Vital Differences. On public Leadership and societal innovation. Inaugural Speech, Wageningen University.

Termeer, C.J.A.M., 2009. Water professionals and public leadership. Irrigation and Drainage 58, S212-S216.

Tierney, K., Bevc, C., Kuligowski, E., 2006. Metaphors Matter: Disaster Myths, Media Frames, and Their Consequences in Hurricane Katrina. The ANNALS of the American Academy of Political and Social Science 604, 57-81.

Tol, R.S.J, Yohe, G.W., 2006. The weakest link hypothesis for adaptive capacity: An empirical test. Global Environmental Change 17, 218-227. 
Tompkins, E.L., Adger, W.N., 2005. Defining response capacity to enhance climate change policy. Environmental Science \& Policy 8, 562-571.

Underdal. A., 1994. Leadership theory: rediscovering the arts of management, in: IIASA, International Multilateral Negotiating: approaches to the management of complexity. Jossey-Bass, San Francisco, pp. 178-197.

Verweij, M., Thompson, M., 2006. Clumsy solutions for a Complex World. Governance, Politics and Plural Perceptions. Palgrave Macmillan, Basingstoke.

Vincent, K., 2006. Uncertainty in adaptive capacity and the importance of scale. Global Environmental Change 17, 12-24.

Walker, B., Carpenter, S., Anderies, J., Abel, N., Cumming, G., Janssen, M., Lebel, L., Norberg, J., Peterson, G., Pritchard, R., 2002. Resilience management in socio-ecological systems: A working hypothesis for a participatory approach. Conservation Ecology 6(1), 14 [online]. Available at http:// www.consecol.org/vol16/iss1/art14.

Wallis, J., Dollery, B., 1997. Autonomous Policy Leadership: Steering a Policy Process in the Direction of a Policy Quest. Governance 10(1), 1-22.

Weick, K.E., Sutcliffe, K.M., 2001. Managing the Unexpected: Assuring High Performance in an Age of Complexity. Jossey-Bass, San Francisco.

Wenger, E., 1998. Communities of Practice: Learning, Meaning, and Identity. Cambridge University Press, Cambridge.

WRR, 2006. Klimaatstrategie - tussen ambitie en realisme. Amsterdam University Press, Amsterdam.

Yohe, G., Neumann, J., Marshall, P., Amaden, H., 1996. The economic cost of greenhouseinduced sea-level rise for developed property in the United States. Climatic Change 32 , $387-410$

Yohe, G., Tol, R.S.J., 2002. Indicators for social and economic coping capacity - moving toward a working definition of adaptive capacity. Global Environmental Change 12, 2540.

Young, O. R., 1989. International Cooperation; Building regimes for natural resources and the environment. Cornell University Press, Ithaca.

Young, O.R., 1991. Political leadership and regime formation: on the development of institutions in international society. International Organisation 45, 3.

Zijderveld, A.C., 2000. The Institutional Imperative - The Interface of Institutions and Networks. Amsterdam University Press, Amsterdam 